\title{
The effect of human serum DNAases on the ability to detect antibiotic-killed Escherichia coli in blood by PCR
}

\author{
ALEXANDRA HEININGER, MARTINA ULRICH*, GREGORY PRIEBE ${ }^{*}, K L A U S$ UNERTL, \\ ALMUT MÜLLER-SCHAUENBURG*, KONRAD BOTZENHART** and GERD DÖRING*
}

Department of Anesthesiology and * Department of General and Environmental Hygiene, Hygiene Institute, University of Tübingen, Germany and †Channing Laboratory of Brigham and Women's Hospital and Departments of Anesthesia and Infectious Diseases of Children's Hospital, Boston, MA, USA

\begin{abstract}
PCR has proved superior to conventional blood culture for diagnosing bacteraemia in the presence of antibiotics. Nevertheless, even PCR might yield false-negative results if the template DNA were to be cleaved by serum DNAases after antibiotics had induced bacterial death. To evaluate the cleavage of bacterial template DNA by human serum DNAase I, serum samples inoculated with purified Escherichia coli DNA were incubated with increasing amounts of recombinant human DNAase (rhDNAase) and then examined by a PCR specific for $E$. coli. As a prerequisite of potential DNAase attack, the release of $E$. coli DNA after antibiotic-induced bacterial death was quantified by fluorescence microscopy and flow cytometry. Finally, the influence of rhDNAase on the PCR-based detection of antibiotic-killed $E$. coli in serum was assessed. The results indicated that purified $E$. coli DNA is remarkably stable in human serum; positive PCR results did not decrease significantly until the ratio of recombinant human DNAase I: $E$. coli rose to $10^{6}: 1$. As only $14.8-28.4 \%$ of the total $E$. coli DNA was released after antibiotic killing, the PCR-based detection of $E$. coli fell by only $10 \%$ when cefotaxime-killed $E$. coli were incubated with rhDNAase. It was concluded that human serum DNAases and antibiotic killing do not compromise the reliability of PCR examinations for bacteraemia.
\end{abstract}

\section{Introduction}

Treatment of patients with broad-spectrum antibiotics increases the risk that bacteria present in the blood remain undetected because it may lead to false-negative blood cultures [1-3]. PCR technology has been shown to overcome some of the weaknesses of conventional culturing methods in such circumstances [2, 4, 5]. For instance, in a rat model of Escherichia coli bacteraemia, PCR was shown to yield a detection rate $80 \%$ higher than that of blood culture in cefotaxime-treated animals [2]. Nevertheless, it is still uncertain just how reliable PCR is and whether a negative result truly reflects the absence of bacteria in blood $[4,5]$, as mechanisms reducing the availability of the bacterial template DNA may cause false-negative PCR results. When bacteria are killed by antibiotics, DNA may be released and then degraded by human endogenous DNAases. However, it is not known to what extent

Received 8 May 200; accepted 27 July 2000.

Corresponding author: Dr G. Döring (e-mail: gerd.doering@ uni-tuebingen.de).
DNAases are active in human serum [6-8]. Furthermore, there are no data quantifying the release of DNA from bacteria after they have been killed by antibiotics. To clarify these points, the effect of human serum DNAase activity on the ability to detect purified E. coli DNA by PCR was investigated. Also, the release of $E$. coli DNA was assessed after incubation with antibiotics with different modes of action. Finally, this study tested whether DNAase compromises the detection of E. coli by PCR in serum when the bacteria have been killed by the antibiotic cefotaxime.

\section{Materials and methods}

\section{E. coli and PCR}

Unless otherwise indicated E. coli ATCC 11229 was cultured overnight in Tryptic Soy Broth (Sigma, Deisenhofen, Germany), centrifuged, washed three times in physiological saline and adjusted to a concentration of $10^{8} \mathrm{cfu} / \mathrm{ml}$, corresponding to an $\mathrm{OD}_{600}$ of 0.12 . The concentration was verified by direct plating of serial dilutions on blood agar and counting colonies after incubation for $24 \mathrm{~h}$ at $37^{\circ} \mathrm{C}$. 
PCR of E. coli DNA was performed as described previously [2] with two pairs of nested primers derived from the uidA gene of $E$. coli encoding $\beta$-glucuronidase. The amplification product was visualised by gel electrophoresis and ethidium bromide staining.

\section{Influence of human DNAases on the detection rate of purified E. coli DNA by PCR}

Twenty samples of serum $(0.1 \mathrm{ml})$ from a healthy individual were each inoculated with $30 \mathrm{pg}$ of purified E. coli DNA (Amersham Pharmacia Biotech, Freiburg, Germany). Native human serum was prepared from venous blood as described for the measurement of DNAase I activity [9]. The reaction mixture was incubated for $2 \mathrm{~h}$ in a water bath at $37^{\circ} \mathrm{C}$. DNAase activity in 20 control samples was inhibited by cooling on ice. To avoid loss of DNA the samples were heated for $10 \mathrm{~min}$ at $94^{\circ} \mathrm{C}$ and then centrifuged for $5 \mathrm{~min}$ at $14000 \mathrm{rpm}$ rather than being subjected to a separate DNA extraction procedure. A $10-\mu 1$ sample of each supernate was used for amplification of $E$. coli DNA by PCR. The minimum number of experiments needed to establish a difference of at least $30 \%$ between samples at $37^{\circ} \mathrm{C}$ and controls was calculated to be 20 .

In a second set of experiments, the quantitative ratio of DNAase to DNA in the samples was varied by adding recombinant human DNAase (rhDNAase; HoffmannLaRoche, Grenzach-Wyhlen, Germany), which is considered to be equivalent to human serum DNAase I $[7,10]$. Ten human serum samples were incubated with $30 \mathrm{pg}$ of purified E. coli DNA and either $30 \mathrm{ng}$ or $30 \mu \mathrm{g}$ of rhDNAase I (final volume $0.1 \mathrm{ml}$ ) and then processed as described above.

To assess a potential inhibition of rhDNAase activity by compounds present in human serum, including sodium, the experiments were repeated in a buffer solution providing optimal conditions for the enzymic activity of rhDNAase $(50 \mathrm{mM}$ Tris- $\mathrm{HCl}$ buffer, $\mathrm{pH} 7.5$, supplemented with $10 \mathrm{mM} \mathrm{MgCl}_{2}$ and $1 \mathrm{~m} \mathrm{M} \mathrm{CaCl} 2$ ) [8]. Then $67 \mu \mathrm{l}$ of the Tris- $\mathrm{HCl}$ buffer, $\mathrm{pH} 7.5$, were spiked with $30 \mathrm{pg}$ of $E$. coli DNA and incubated with rhDNAase ( $3 \mathrm{pg}, 30 \mathrm{pg}, 300 \mathrm{pg}, 3 \mathrm{ng}, 300 \mathrm{ng}$ ) in a final volume of $0.1 \mathrm{ml}$ for $2 \mathrm{~h}$ at $37^{\circ} \mathrm{C}$. Ten $\mu \mathrm{l}$ of the reaction mixture were used for amplification of $E$. coli DNA by PCR. It was determined that a minimum of 10 experiments would be necessary to establish a relevant difference of at least $80 \%$ between samples spiked with rhDNAase and controls.

\section{Assessment of DNA release from E. coli after treatment with antibiotics}

Samples of an E. coli suspension $(1 \mathrm{ml})$ in physiological saline $\left(10^{8} \mathrm{cfu} / \mathrm{ml}\right)$ were incubated with $100 \mu \mathrm{l}$ of cefotaxime, ciprofloxacin, imipenem or gentamicin (final antimicrobial concentrations: 5, 0.2, 5 and $4 \mathrm{mg} / \mathrm{L}$, respectively) at $4^{\circ} \mathrm{C}$ for $2 \mathrm{~h}$. Complete bacterial killing was verified after $15 \mathrm{~min}$ by plating
$100 \mu \mathrm{l}$ on to blood agar and counting colonies after incubating the plates for $24 \mathrm{~h}$ at $37^{\circ} \mathrm{C}$. Controls contained E. coli in $1100 \mu \mathrm{l}$ of physiological saline without antibiotics. After $2 \mathrm{~h}, 10 \mu \mathrm{l}$ of the E. coli suspension were heat-fixed on microscope slides and the DNA was stained with $25 \mu \mathrm{l}$ of the nucleic acid dye 4',6-diamidino-2-phenylindole (DAPI; Sigma) $2 \mu \mathrm{l} / \mathrm{ml}$ for $5 \mathrm{~min}$ in the dark. Bacteria were embedded in Dako fluorescent mounting medium (Dako, Copenhagen, Denmark). For each antibiotic and the respective controls, 10 visual fields were randomly chosen and evaluated with an Axioplan microscope (Zeiss, Oberkochen, Germany) in both the fluorescence and phasecontrast modes for each visual field. Pictures were taken at a magnification of 1000 and digitalised with the KS 300 digital image processing system (Kontron Electronic GmbH, Eching, Germany). The bacterial count was performed by two independent observers; the number of bacteria obtained in the phase-contrast mode was taken as the total bacterial count and set at $100 \%$. The percentage of bacteria that had released DNA was calculated as the difference between the total bacterial count and the number of bacteria which remained visible in the fluorescence mode.

In addition, flow cytometry was used to assess the release of DNA from $E$. coli after antibiotic treatment. $E$. coli grown overnight on tryptic soy agar plates was suspended to $10^{9} \mathrm{cfu} / \mathrm{ml}\left(\mathrm{OD}_{650} 0.75\right)$ in $10 \mathrm{ml}$ of phosphate-buffered saline (PBS). DAPI (10 $\mu \mathrm{l}$ of a $3 \mathrm{mM}$ suspension in water) was added to $1-\mathrm{ml}$ samples of the bacterial suspension to yield a final DAPI concentration of $30 \mu \mathrm{M}$. The resulting suspension was mixed and incubated at room temperature for $60 \mathrm{~min}$ in the dark. Bacteria were centrifuged eight times $(8000 \mathrm{rpm}$ in a microfuge for $15 \mathrm{~min}$ at room temperature); after each centrifugation the bacteria were washed in PBS. The pellets of stained bacteria from the last centrifugation were suspended to a final volume of $1 \mathrm{ml}$ in PBS containing cefotaxime $5 \mathrm{mg} / \mathrm{L}$ (for treated samples) or PBS alone (for untreated samples). These samples were incubated at $4^{\circ} \mathrm{C}$. After $30 \mathrm{~min}, 10-\mu 1$ samples were plated on blood agar and incubated overnight at $37^{\circ} \mathrm{C}$ to monitor bacterial killing. Control samples contained bacteria not stained with DAPI and either with or without exposure to cefotaxime. After another $90 \mathrm{~min}$ (a total of $2 \mathrm{~h}$ after exposure to cefotaxime), bacterial fluorescence was measured by flow cytometry (Coulter Elite ESP flow cytometer) with a UV-enhanced argon laser for excitation and a 405-nm bandpass filter set for emission. Approximately 5000 events were recorded for each sample. The percentage of bacteria with fluorescence lower than the mean fluorescence of the untreated controls was used as a measure of DNA loss.

\section{Influence of human DNAases on the detection of cefotaxime-killed E. coli by PCR}

E. coli were incubated with $20 \mu \mathrm{g}$ of cefotaxime for $15 \mathrm{~min}$ at $37^{\circ} \mathrm{C}$ in $0.9 \mathrm{ml}$ of Tris- $\mathrm{HCl}$ buffer or human 
serum (final volume $1 \mathrm{ml}$; final bacterial concentration $10 \mathrm{cfu} / \mathrm{ml}$ ). Then 20 buffer and 30 serum samples were each incubated with either $50 \mathrm{ng}$ or $50 \mu \mathrm{g}$ of rhDNAase (final volume $1.5 \mathrm{ml}$ ) for $2 \mathrm{~h}$ at $37^{\circ} \mathrm{C}$, resulting in ratios of rhDNAase to total E. coli DNA content of $10^{6}: 1$ and $10^{9}: 1$. As controls, 40 buffer and 60 serum samples were incubated with $0.5 \mathrm{ml}$ of buffer instead of rhDNAase. After incubation, E. coli DNA was extracted with the Purgene DNA isolation kit for gram-negative bacteria (Biozym Diagnostik $\mathrm{GmbH}$, Hessisch Oldendorf, Germany) according to the manufacturer's protocol; the total DNA was used for PCR. It was calculated that the numbers of experiments necessary to determine a $30 \%$ decrease of positive PCR results in buffer and serum were 20 and 30, respectively.

\section{Statistical analysis}

In all experiments, Fisher's exact test was applied for statistical analysis with the SAS software system, version 6.12 (Cary, USA). The level of significance was set to 0.05 [11].

\section{Results}

Influence of human DNAases on the detection rate of purified E. coli DNA by PCR

When purified E. coli DNA was incubated in human serum for $2 \mathrm{~h}$ at $37^{\circ} \mathrm{C}$ and then put into the nested PCR, 18 of 20 reactions were positive. In the control experiment in which DNAase activity was inhibited by holding at $4^{\circ} \mathrm{C}, 18$ of 20 reactions were positive, indicating that endogenous DNAase activity does not degrade the $E$. coli template DNA to a degree sufficient to impair the PCR reaction. To determine the threshold at which the detection rate drops noticeably, increasing amounts of rhDNAase were added to serum spiked with $30 \mathrm{pg}$ of purified bacterial DNA. The E. coli DNA was detected by PCR in all 10 samples tested when the ratio of DNAase to $E$. coli DNA was $10^{3}: 1$; detection was impaired significantly (2 of 10 samples positive) at a weight ratio of rhDNAase I:DNA of $10^{6}: 1$ (Fig. 1a). When the experiments were performed in Tris-HCl buffer the threshold value for significant PCR impairment was reached at a rhDNAase:DNA ratio of $10^{4}: 1$ (Fig. 1b).

\section{DNA release from E. coli after antibiotic treatment}

Killing E. coli with cefotaxime, ciprofloxacin, imipenem and gentamicin caused a loss of DAPI-positive $E$. coli cells in the range $15-28 \%$ (Fig. 2, Table 1). Based on a mean DNA content of $5 \mathrm{fg} / E$. coli cell [12], the observed loss of DAPI-positive E. coli corresponds to an antibiotic-induced loss of DNA between $14.2 \mathrm{fg}$ and $7.4 \mathrm{fg}$ per sign 10 micro-organisms. By flow cytometry, the mean fluorescence of DAPI-stained organisms decreased by $16 \%$ after treatment with cefotaxime for

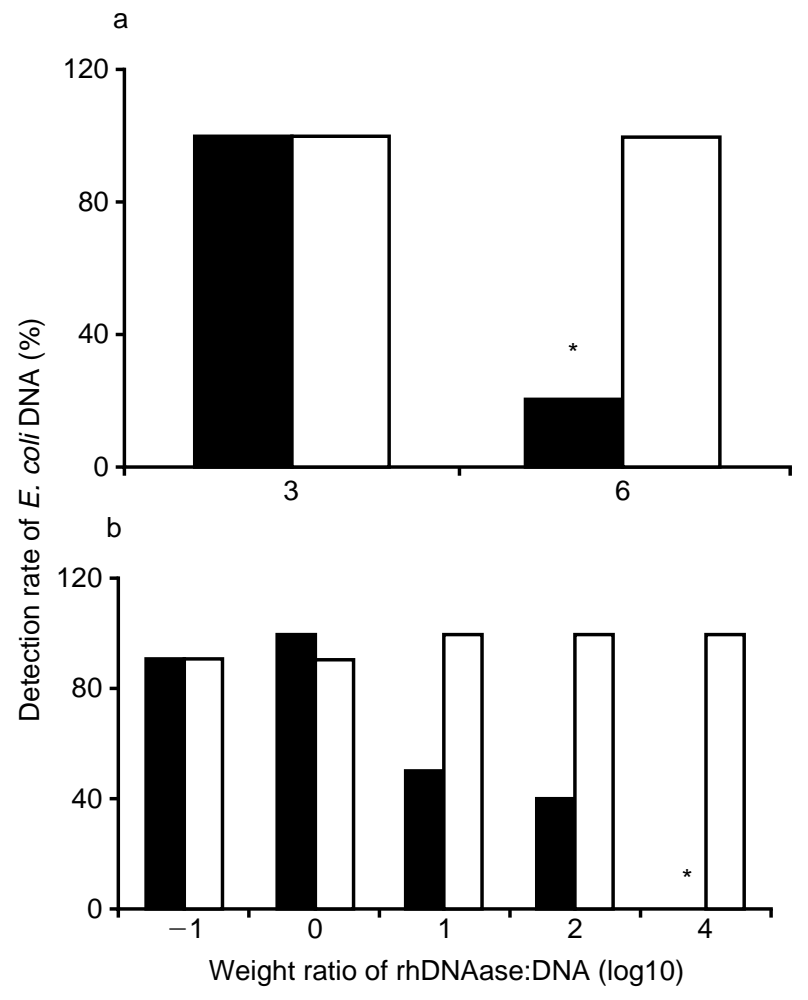

Fig. 1. Detection of purified $E$. coli DNA by PCR in human serum and buffer and influence of recombinant human DNAase. Human serum (a) or buffer (b) was inoculated with $30 \mathrm{pg}$ of $E$. coli DNA and incubated with increasing amounts of rhDNAase (ם) or buffer for control ( $\square$ ) for $2 \mathrm{~h}$ at $37^{\circ} \mathrm{C}$ (final volume: $1.1 \mathrm{ml}$ ), resulting in weight proportions of rhDNAase $\mathrm{I}: E$. coli DNA as indicated on the horizontal axis. Thereafter, 10$\mu 1$ samples were used for amplification of a 486-bp fragment of the uidA gene of $E$. coli by PCR. ${ }^{*} \mathrm{p}<0.05$.

$2 \mathrm{~h}$ (Fig. 3). Unstained E. coli with and without cefotaxime treatment showed no appreciable autofluorescence (data not shown). These results show that although bactericidal concentrations of antibiotics had been used, which led to complete cell death within 15 min, a remarkable amount of DNA was still present within the cells after $2 \mathrm{~h}$.

\section{Influence of human DNAases on the detection of cefotaxime-killed E. coli by PCR}

When cefotaxime-killed $E$. coli were incubated with large amounts of rhDNAase in serum and the samples were then examined by PCR, the $E$. coli detection rate did not drop significantly. At a calculated weight ratio of rhDNAase to total E. coli DNA content of $10^{6}: 1, E$. coli DNA was detected in 17 of 30 samples by PCR. In controls without the addition of rhDNAase, the presence of $E$. coli DNA was detected in 17 of 30 serum samples. At a rhDNAase:DNA ratio of $10^{9}: 1,20(66 \%)$ of 30 PCR results were positive; in the controls, 23 $(76 \%)$ of 30 reactions were positive. Even when the reaction was performed in buffer in which rhDNAase activity was $>10^{2}$ times higher than in serum, no significant differences were seen between the PCR detection rates of rhDNAase-treated and untreated 

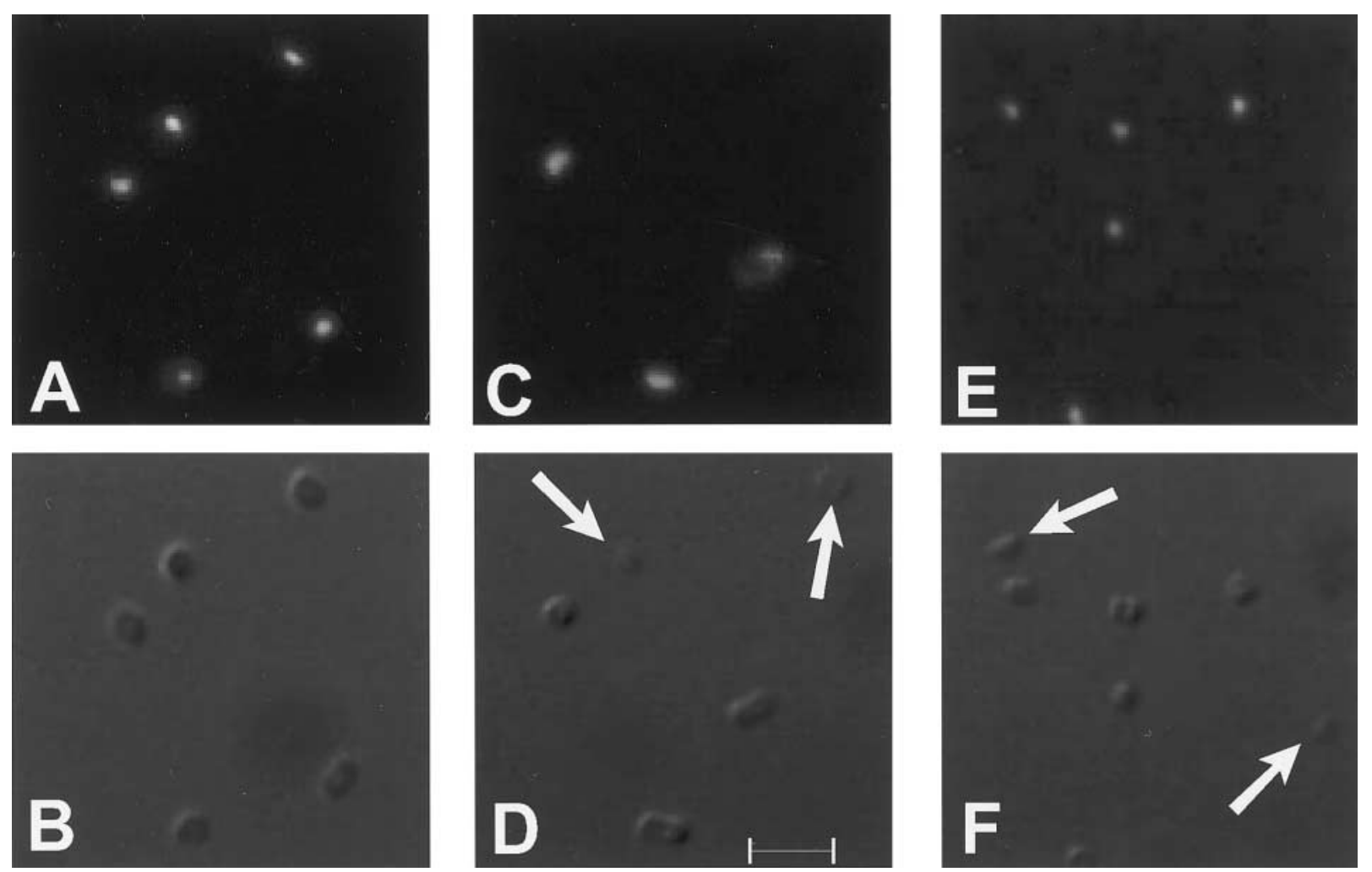

Fig. 2. Release of DNA from E. coli after antibiotic treatment. E. coli were incubated with buffer (A, B) or bactericidal concentrations of cefotaxime $(\mathbf{C}, \mathbf{D})$ or imipenem $(\mathbf{E}, \mathbf{F})$ at $4^{\circ} \mathrm{C}$ for $2 \mathrm{~h}$ and $15 \mathrm{~min}$, then stained with DAPI and analysed by fluorescence $(\mathbf{A}, \mathbf{C}, \mathbf{E})$ and phase-contrast (B, D, F) microscopy Magnification $\times 1000 ;$ bar $5 \mu \mathrm{m}$. Arrows mark bacteria visible in phase-contrast and not visible by fluorescence.

Table 1. DNA release from E. coli after antibiotic treatment in vitro

\begin{tabular}{lcccr}
\hline & \multicolumn{3}{c}{ Bacterial numbers } & \multicolumn{2}{c}{$\begin{array}{c}\text { Calculated amount of } \\
\text { lost DNA } \\
\text { Treatment* }\end{array}$} & Phase-contrast & Fluorescense & Difference (\%) & E. coli) \\
\hline \cline { 2 - 4 } None & $44.7(30.7)$ & $42.3(29.2)$ & $4.7(4.1)$ & 2.3 \\
Cefotaxime & $38.9(11.2)$ & $28.0(14.6)$ & $28.4(9.1)$ & 14.2 \\
Ciprofloxacin & $58.3(33.1)$ & $46.8(29.8)$ & $20.4(7.1)$ & 10.2 \\
Imipenem & $42.6(28.2)$ & $35.1(22.1)$ & $17.6(3.3)$ & 8.8 \\
Gentamicin & $36.4(19.1)$ & $30.8(16.0)$ & $14.8(9.5)$ & 7.4 \\
\hline
\end{tabular}

${ }^{*}$ E. coli were incubated with buffer, or bactericidal concentrations of cefotaxime, ciprofloxacin, imipenem or gentamicin at $4^{\circ} \mathrm{C}$ for $2 \mathrm{~h}$ and $15 \mathrm{~min}$, then stained with DAPI.

${ }^{\dagger}$ The numbers of bacterial cells were analysed by fluorescence and phase-contrast microscopy in 10 randomly chosen identical visual fields. The number of bacteria in the phase contrast was set at $100 \%$. The percentage of bacteria that had lost DNA was quantified by counting DAPI-stained bacteria in the fluorescence mode and comparison with the bacterial number in the phase contrast mode. Values represent means (SD).

${ }^{*}$ The loss of DNA from $10 \mathrm{E}$. coli cells was calculated from the difference between DAPI-stained cells and cells visible by phase-contrast microscopy based on a mean DNA content of $5 \mathrm{fg} / \mathrm{cell}$.

controls. At a calculated ratio of rhDNAase: E. coli DNA of $10^{6}: 1$, PCR demonstrated the presence of $E$. coli in $17(85 \%)$ of 20 samples, which did not differ from the control experiments. At a rhDNAase: $E$. coli DNA ratio of $10^{9}: 1$ the PCR detection rate for $E$. coli was $16(80 \%)$ of 20 ; in controls it was $18(90 \%)$ of 20 . This observation suggests that the DNA content of $E$. coli is protected from DNAase attack even after the bacteria have been killed by antibiotics.

\section{Discussion}

The ability to detect bacteria independently of propagation makes the PCR technique attractive for diagnosing bacteraemia during antibiotic treatment. The results of the present study further confirm the reliability of the PCR method for this purpose. This reliability can be explained by the findings that antibiotic-killed E. coli do not release a large proportion of their DNA into the bloodstream and that the released bacterial DNA is not readily degraded by blood DNAases.

Surprisingly little is known about the release of bacterial DNA after antibiotic treatment. Gentamicin treatment of $E$. coli was reported to cause leakage of most of the DNA, but exact data were not given [13]. 


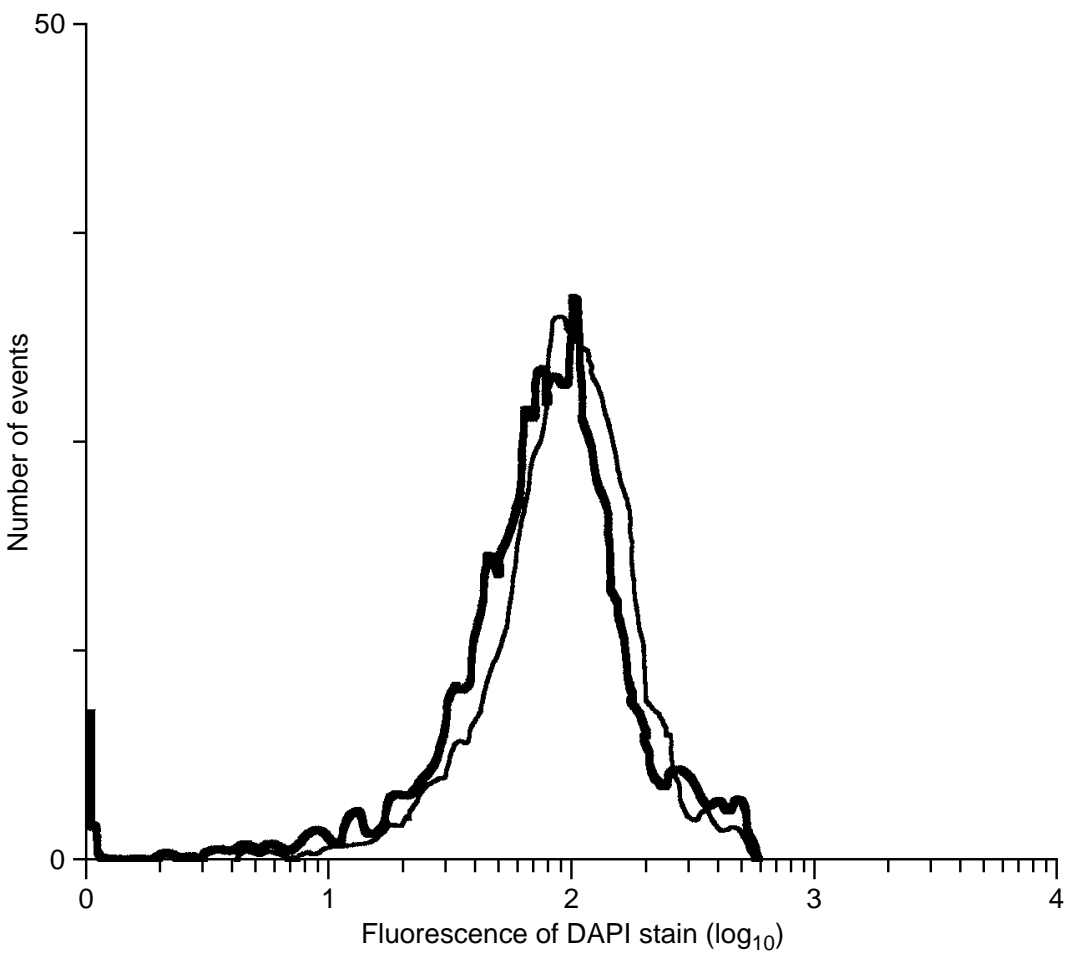

Fig. 3. Release of DNA from E. coli after cefotaxime treatment measured by flow cytometry. DAPI-stained $E$. coli were incubated with bactericidal concentrations of cefotaxime (-) or with PBS alone (-) at $4^{\circ} \mathrm{C}$ for $2 \mathrm{~h}$ and analysed by flow cytometry. Unstained E. coli (with or without cefotaxime) had minimal fluorescence (data not shown).

Legionella pneumophila released $50 \%$ of its radiolabelled DNA $3 \mathrm{~h}$ after treatment with penicillin $\mathrm{G}$ [14]. In the present study, it was observed by phase-contrast and fluorescence microscopy that $15-30 \%$ of the $E$. coli DNA was released after treatment with cefotaxime, ciprofloxacin, imipenem or gentamicin. Similarly, flow cytometry showed that the mean amount of DAPIstained DNA decreased by $16 \%$ after treatment with cefotaxime. This moderate difference might be explained by the different methods used to assess the DNA release and by different modes of action of the antibiotics used.

Human serum DNAases are known to digest doublestranded DNA down to tri- or tetra-oligodeoxynucleotides in vitro $[8,15]$ and to digest therapeutically applied synthetic oligodeoxynucleotides in mammalian serum $[16,17]$. In contrast, in the present study it was observed that cleavage of purified E. coli DNA to a degree sufficient to influence the PCR results occurred only at high weight ratios of DNAase to DNA. This contradiction might be explained by three facts. Firstly, because of the high sensitivity of the PCR method even minimal residues of uncleaved DNA yield positive results. Secondly, it has been suggested that the sodium concentration in human serum might decrease human DNAase activity [7, 18]. Finally, a protective effect of histone-like proteins against degradation by DNAases has been described in genomic E. coli DNA sequences [19], whereas synthetic oligodeoxynucleotides lack these protective compounds.
The observation that even large amounts of rhDNAase reduced the PCR-based detection of 10 E. coli per ml of serum by $10 \%$ at most suggests that the detection of higher bacterial concentrations would not be compromised by either antibiotic treatment or plasma DNAases, as the amount of DNA still available for amplification far exceeds the sensitivity limit. Thus, in bacteraemia of children - where bacterial concentrations of 10-100 micro-organisms $/ \mathrm{ml}$ of blood are reported [20] - the use of the PCR technique might be particularly promising for achieving a diagnosis during antibiotic treatment.

We are indebted to A. Dalhoff of Bayer Vital AG, Leverkusen, Germany for discussions concerning the release of bacterial DNA after antibiotic treatment; to M. Putzenlechner of Hofmann-La Roche, Grenzach-Wyhlen, Germany for the kind gift of rhDNAaseI; and to C. Meisner, Institut für Biometrie of the University of Tübingen for assistance in the statistical evaluation of the data.

\section{References}

1. Darby JM, Linden P, Pasculle W, Saul M. Utilization and diagnostic yield of blood cultures in a surgical intensive care unit. Crit Care Med 1997; 25: 989-994.

2. Heininger A, Binder M, Schmidt S, Unertl K, Botzenhart K, Döring G. PCR and blood culture for detection of Escherichia coli bacteremia in rats. J Clin Microbiol 1999; 37: 2479-2482.

3. McKenzie R, Reimer LG. Effect of antimicrobials on blood cultures in endocarditis. Diagn Microbiol Infect Dis 1987; 8: $165-172$.

4. Ley BE, Linton CJ, Bennett DMC, Jalal H, Foot ABM, Millar MR. Detection of bacteremia in patients with fever and neutropenia using 16S rRNA gene amplification by polymerase chain reaction. Eur J Clin Microbiol Infect Dis 1998; 17: 247-253. 
5. Cursons RTM, Jeyerajah E, Sleigh JW. The use of polymerase chain reaction to detect septicemia in critically ill patients. Crit Care Med 1999; 27: 937-940.

6. Gupta S, Herriott RM. Nucleases and their inhibitors in the cellular components of human blood. Arch Biochem Biophys 1963; 101: 88-95.

7. Prince WS, Baker DL, Dodge AH, Ahmed AE, Chestnut RW, Sinicropi DV. Pharmacodynamics of recombinant human Dnase I in serum. Clin Exp Immunol 1998; 113: 289-296

8. Love JD, Hewitt RR. The relationship between human serum and human pancreatic DNase I. J Biol Chem 1979; 254: $12588-12594$

9. Nadano D, Yasuda T, Kishi K. Measurement of deoxyribonuclease I activity in human tissues and body fluids by a single radial enzyme-diffusion method. Clin Chem 1993; 39: 448452 .

10. Witt DM, Anderson L. Dornase alfa: a new option in the management of cystic fibrosis. Pharmacotherapy 1996; 16: 40-48.

11. Altmann DG. Comparing groups - categorical data. In: Practical statistics for medical research. London, Chapman and Hall. 1991: 229-276.

12. Rattanathongkom A, Sermswan RW, Wongratancheewin S Detection of Burkholderia pseudomallei in blood samples using polymerase chain reaction. Mol Cell Probes 1997; 11: $25-31$.
13. Walberg M, Gaustad P, Steen HB. Rapid assessment of ceftazidime, ciprofloxacin, and gentamicin susceptibility in exponentially-growing $E$. coli cells by means of flow cytometry. Cytometry 1997; 27: 169-178.

14. Weisholtz S, Tomasz A. Response of Legionella pneumophila to beta-lactam antibiotics. Antimicrob Agents Chemother 1985; 27: 695-700.

15. Peitsch MC, Polzar B, Tschopp J, Mannherz HG. About the involvement of deoxyribonuclease I in apoptosis. Death and Differentiation 1994; 1: 1-6.

16. Wickstrom E. Oligodeoxynucleotide stability in subcellular extracts and culture media. J Biochem Biophys Methods 1986; 13: $97-102$.

17. Zamecnik PC, Goodchild J, Taguchi Y, Sarin PS. Inhibition of replication and expression of human T-cell lymphotropic virus type III in cultured cells by exogenous synthetic olignonucleotides complementary to viral RNA. Proc Natl Acad Sci USA 1986; 83: 4143-4146.

18. Shelev I, Legina O, Tutaev K, Krutyakov V. Strong inhibition of endodeoxyribonucleases at physiological ion strength. Mol Biol 1997; 32: 617-620.

19. Tsui P, Freundlich M. Integration host factor binds specifically to sites in the ilvGMEDA operon in Escherichia coli. $\mathrm{J} \mathrm{Mol}$ Biol 1988; 203: 817-820.

20. Yagupski P, Nolte FS. Quantitative aspects of septicemia. Clin Microbiol Rev 1990; 3: 269-279. 